\title{
Strategi Koping Lansia dengan Tempat Tinggal di Ulee Kareng Banda Aceh
}

\author{
Susi Andriani ${ }^{1}$, Arti Lukitasari ${ }^{2}$, Kartini Hasbalah ${ }^{3}$ \\ ${ }^{1}$ STIKes Medika Nurul Islam Sigli \\ ${ }^{2,3}$ Magister Keperawatan Universitas Syiah Kuala \\ E-mail/No HP : susiandriani2019@gmail.com/082165655412
}

\begin{abstract}
ABSTRAK
Strategi koping merupakan cara yang dilakukan lansia dalam menyelesaikan masalah, menyesuiakan diri dengan perubahan, serta respon terhadap situasi yang mengancam. Tujuan penelitian ini untuk mengetahui perbedaan strategi koping pada lansia yang tinggal di rumah dengan di Panti. Jenis penelitian adalah kuantitatif menggunakan desain deskriptif komparatif dengan pendekatan Cross Sectional Study. Pengambilan sampel dengan cara total sampling pada lansia di UPTD Rumoh Seujahtra Geunaseh Sayang dan propotional Sampling di rumah, sampel berjumlah 106 lansia. Analisis hasil penelitian meliputi analisa univariat dan bivariat yang menggunakan uji Chi Square. Hasil penelitian menunjukkan ada hubungan strategi problem focused copin dan emotional focused coping ( $p=0.001)$, dan tidak ada hubungan strategi religious coping dengan lansia yang tinggal di rumah dan panti $(p>0.05)$. Disarankan perlu dilakukan berbagai intervensi penyuluhan mekanisme koping dan pada lansia di panti untuk meningkatkan strategi koping dan kualitas hidup yang baik pada lansia yang tinggal di panti dan di rumah.
\end{abstract}

Kata Kunci: Strategi Koping, lansia, tempat tinggal.

\begin{abstract}
Elderly use coping strategy to solve problems, to adapt whit changes, and to respond a threatening situation. The purpose of this study was to find out the differences of coping strategies between elderly living at home and at Panti. The research employed quantitative menthode by using comparative descriptive design with cross sectional study approach. Sample was selected by using total sampling for elderly who lived in Panti and proportional sampling for elderly who lived at home. The number of sample was 106 alderly. The result analysis included study univariate and bivariat analysis by chi-square test. The results showed that threre were the differences in coping strategies of elderly who lived at home and at regional technical implementation in panti $(\mathrm{p}=0.001)$. It is suggested that it is necessary to undertake intervention in older to improve coping strategies and quality of life in elderly who live people living in nursing home.
\end{abstract}

Keywords: Coping strategy, elderly, living 
Serambi Saintia

Volume VII, No.2, Oktober 2019

pISSN $2337-9952$

Jurnal Sains dan Aplikasi

eISSN $2656-8446$

\section{PENDAHULUAN}

Lanjut usia merupakan proses yang akan dialami oleh setiap orang yang mendapatkan karunia umur panjang (Hayflick, 1994 dalam Stanhope \& Lancaster, 2004). Menurut Undang-undang Nomor 13 tahun 1998 tentang Kesejahteraan Lanjut Usia, menyebutkan batasan Lanjut usia adalah kelompok penduduk yang berusia 60 tahun keatas. Kelompok ini memerlukan perhatian khusus, mengingat bahwa jumlahnya yang semakin meningkat (Notoatmojo, 2007).

Masa lansia sering diidentikkan dengan masa penurunan dan ketidakberdayaan, walaupun tidak sepenuhnya benar namun seiring bertambahnya usia, lansia memang mengalami beberapa penurunan fungsi fisik, perubahan biologis, psikologis dan spiritual yang menjadikannya semakin rentan terhadap penyakit-penyakit kronis (Sunaryo, 2004).

Usia harapan hidup orang Indonesia semakin meningkat seiring dengan meningkatnya taraf hidup dan pelayanan kesehatan. Dengan semakin meningkatnya usia harapan hidup penduduk, menyebabkan jumlah penduduk lanjut usia terus meningkat dari tahun ke tahun. Diperkirakan persentase penduduk lanjut usia akan mencapai 9,77 persen dari total penduduk pada tahun 2010 dan menjadi 11, 34 persen pada tahun 2020 (Hernama, 2011).

Menurut Badan Pusat Statistik (2009), Jumlah penduduk lanjut usia perempuan lebih banyak dibandingkan laki-laki, lansia perempuan 11,29 juta jiwa dan lansia laki-laki 9,26 juta jiwa oleh karena itu, permasalahan lanjut usia secara umum di Indonesia, adalah permasalahan yang lebih didominasi oleh perempuan, dimana usia hidup perempuan lebih panjang dibandingkan laki-laki, antara lain karena suaminya meninggal lebih dulu, dan karena gender perempuan terbiasa mengurus dirinya sendiri (Sunaryo, 2004)

Lansia sering mengalami berbagai masalah fisik, mental, sosial, ekonomi dan psikologis, Salah satu masalah psikologis yang dapat dialami oleh lansia adalah stres (Miller, 2004). Menurut Wood (1993) stres merupakan reaksi tubuh terhadap sesuatu yang menimbulkan tekanan, perubahan dan ketegangan emosi.

Stres pada lansia dapat diakibatkan oleh beberapa hal yaitu pertama masalah yang disebabkan oleh perubahan hidup dan kemunduran fisik yang dialami oleh lansia, kedua lansia yang sering mengalami kesepian yang disebabkan oleh putusnya hubungan dengan orang-orang yang paling dekat dan disayangi, ketiga post power syndrome, hal ini banyak dialami lansia yang baru saja mengalami pensiun, kehilangan kekuatan, penghasilan dan kebahagiaan (Martono, 2006).

Setiap lansia mendambakan masa tua yang tenang dan bahagia yang didukung oleh tempat tinggal yang nyaman. Terdapat dua pilihan tempat tinggal untuk merawat lansia, dimana lansia dapat dirawat dalam rawatan institusional atau non institusional. Salah satu bentuk perawatan institusional bagi lansia adalah Panti Wredha, dimana Panti Wredha merupakan sebuah tempat tinggal sebagai perwujudan pelayanan sosial terhadap lansia yang terlantar atau tidak mempunyai keluarga maupun lansia dari keluarga yang tidak mampu untuk diberikan perawatan atau pelayanan (sandang, pangan, papan, dan kesehatan), melaksanakan kesehatan, melaksanakan bimbingan mental, spiritual sehingga lansia dapat merasa aman dan tenang dalam menikmati masa tuanya, dimana keluarga dari lansia mempunyai keterbatasan waktu, dana, tenaga, dan kemampuan untuk merawat lansia, maka tempat tinggal yang menjadi pilihan adalah Panti Wredha (Versayanti, 2008).

Menurut Nugroho, (2000) pandangan sebagian lansia keberadan di Panti adalah akibat penolakan keluarga terhadap dirinya sehingga membuat mereka semakin stres 
berada di Panti. Beberapa hasil studi ditemukan bahwa penempatan lansia di Panti Wredha bisa mendatangkan stres yang diakibatkan oleh timbulnya pertengkaran, ketakutan, kecemasan, dan menarik diri (Versayanti, 2008). Lansia seringkali menghayati penempatan mereka di Panti sebagai bentuk pengasingan dan pemisahan diri dari perasaan kehangatan yang terdapat dalam keluarga, apalagi lansia yang masih punya anak dengan kondisi hidup bercukupan. Perasaan-perasaan negatif akan muncul dalam benak lansia dimana pada saat tertentu perasaan-perasaan tersebut akan timbul dan menimbulkan stres (Watson, 2003).

Rumah adalah tempat yang paling baik bagi seorang lansia. Perawatan dirumah sebagai contoh perawatan non institusi merupakan jenis pelayanan kesehatan yang berbasis pada komunitas dan berfokus pada pemberi pelayanan kesehatan untuk lansia yang dilakukan dalam lingkungan tempat tinggal. Sementara orang yang tepat memberikan bantuan dan dukungan emosional adalah keluarga, karena keluarga adalah komunitas kecil yang terdekat dengan lansia. Keluarga merupakan pendukung utama dalam memberikan perawatan terhadap lansia yang tinggal di rumah, namun banyak juga permasalahan yang terjadi dalam keluarga yang menjadi stressor bagi lansia. Dari hasil penelitian bahwa persentase stres lansia yang tinggal dirumah lebih rendah dibanding tinggal di Panti (Versayanti, 2008).

Mekanisme pertahanan diri terhadap koping adalah pemecahan masalah yang digunakan untuk mengelola stres (Keliat, 1999). Kemampuan koping dengan adaptasi terhadap stres merupakan faktor penentu yang penting dalam kesejahteraan manusia. Penggunaan strategi koping sangat mempengaruhi kemampuan seseorang mengatasi sumber stres, jika seseorang mampu mengatasi sumber stres dengan menggunakan strategi koping yang efektif, maka stres akan menurun/tidak akan terjadi, namun jika individu tidak mampu melakukan koping yang efektif maka akan tetap berada dalam situasi stres atau meningkat (Wenger, 2003).

Upaya intervensi keperawatan selayaknya dapat meningkatkan kesejahteraan lansia dengan adanya perubahan pola hidup kearah yang lebih sehat, dengan mengembangkan intervensi yang mengarah pada upaya promotif, preventif, dan pemberdayaaan potensi yang ada di masyarakat tanpa mengabaikan upaya kuratif serta rehabilitasi untuk memelihara dan meningkatkan status kesehatan pada lansia (Prabowo, 2007).

Unit Pelaksana Teknis Dinas Rumoh Geunaseh Sayang merupakan tempat pelayanan sosial milik Pemerintah Aceh yang bertujuan untuk menampung lansia terlantar tidak punyak keluarga dan dari keluarga yang tidak mampu. UPTD Rumoh Seujahtra Geunaseh Sayang berlokasikan di jalan T. Iskandar Ulee Kareng Banda Aceh. Dari hasil survey dan wawancara penulis dengan kepala UPTD ditemukan data bahwa petugas panti terdiri dari seorang kepala panti, 3 tenaga kesehatan termasuk dokter umum dan perawat DIII serta 21 orang pengurus lainnya.

Permasalahan kesehatan yang dialami lansia di Panti sangat bervariasi mulai dari penyakit fisik yang paling banyak terjadi antara lain hipertensi, rheumatik, diabetes mellitus, osteoartitis, asma, dermatitis, dan lain-lain. UPTD Rumoh Seujahtra Geunaseh Sayang dihuni oleh 70 lansia yang terdiri dari lansia perempuan 46 orang dan lansia laki-laki 24 orang yang berumur $60 \mathrm{~s} / \mathrm{d} 90$ tahun dan berasal dari berbagai daerah seluruh Aceh (Data dari UPTD Rumah Seujahtra Geunaseh Sayang, 2014). Perbedaan daerah asal membawa pengaruh terhadap kebiasaan, gaya bicara dan tingkah lakunya, disamping latar belakang pendidikan dan pengalaman masa lalu lansia juga berpengaruh dalam segala perbuatannya (Sugandi, 2014) 
Ulee Kareng adalah suatu kecamatan di Kota Banda Aceh yang terdiri dari 8 desa yaitu gampong Ceurih, Doy, Ie Masen, Ilie, Lamglumpang, Lambhuk, Pango Raya, Pango Deah. Gampong Ceurih mempunyai lansia perempuan 53 orang, Doy mempunyai lansia perempuan 48 orang, Ie masen mempunyai lansia perempuan 32 orang, Ilie mempunyai lansia perempuan 80 orang, Lamglumpang mempunyai lansia perempuan 38 orang, Lambhuk mempunyai lansia perempuan 14 orang, Pango Raya mempunyai lansia perempuan 37 orang, Pango Deah mempunyai lansia perempuan 12 orang, jumlah keseluruhan lansia 314 orang (Data dari kecamatan Ulee Kareng Banda Aceh, 2014)

Dalam penelitian ini peniliti melihat lansia yang tinggal bersama keluarga dan di UPTD Rumoh Seujahtra Geunaseh Sayang di Puskesmas Ulee Kareng. Penelitian ini adalah analitik dengan pendekatan cross sectional study dengan jumlah sampel lansia bersama keluarga yaitu 314 lansia perempuan dan jumlah lansia di UPTD Rumoh Seujahtra Geunaseh Sayang yaitu 46 lansia perempuan juga. Selama ini di wilayah Ulee Kareng belum ada penelitian tentang strategi koping lansia.

Dari uraian di atas menunjukkan bahwa berbagai fenomena dari para ahli maupun dari masyarakat tentang respon yang muncul ketika seseorang dihadapkan pada situasi stres, baik pada lansia yang tinggal bersama keluarga dan di panti, dimana kedua tempat tinggalnya tersebut dapat menimbulkan stres dengan tingkatan yang berbeda. Potter \& Perry (2005) mengkategorikan tingkat stres menjadi empat yaitu tidak stres, tingkat stres ringan, sedang, dan tinggi.

\section{METODE PENELITIAN \\ Desain penelitian}

Penelitian ini adalah penelitian analitik dengan menggunakan pendekatan cross sectional yang bertujuan untuk menggambarkan hubungan antar variabel.

\section{Populasi dan sampel}

Populasi penelitian ini adalah seluruh lansia perempuan yang tinggal bersama keluarga di Wilayah Puskesmas Ulee Kareng Kota Banda Aceh berjumlah 314 orang, dan lansia perempuan yang tinggal di Panti 46. Teknik pengambilan sampel total sampling untuk lansia di Panti dan Propotional lansia yang tinggal dirumah. Sampel berjumlah 106 orang.

\section{Tempat dan Waktu Penelitian}

Penelitian ini dilakukan di Wilayah Puskesmas Ulee Kareng Kota Banda Aceh dan di Panti. Penelitian dilaksanakan pada bulan Januari sampai dengan Desember tahun 2014.

\section{HASIL PENELITIAN}

Hasil Hasil analisa statistik karakteristik responden menggambarkan distribusi responden yang tinggal dirumah berdasarkan umur, pendidikan, status perkawinan dapat dilihat pada tabel 1 . 
Susi Andriani, Arti Lukitasari, Kartini Hasbalah

Tabel. 1. Distribusi Responden Berdasarkan Kategori Umur, Pendidikan,Status Perkawinan, Di Rumah (N=60)

\begin{tabular}{ccc}
\hline \multirow{2}{*}{ Variabel } & \multicolumn{2}{c}{ Jumlah } \\
\cline { 2 - 3 } & Frekuensi & Persentasi (\%) \\
\hline Umur (tahun) & 33 & 55 \\
1. $60-74$ & 27 & 45 \\
2. $75-90$ & 0 & 0 \\
3. >90 & & \\
Pendidikan & 45 & 75 \\
1. SD & 15 & 25 \\
2. SMP & 0 & 0 \\
3. SMA & & \\
Status Perkawinan & 35 & 58.3 \\
1. Menikah & 25 & 41.7 \\
2. Janda & & \\
\hline
\end{tabular}

Berdasarkan tabel 4.1karakteristik lansia menurut umur, pendidikan dan status perkawinan lansia yang tinggal dirumah diketahui proporsi lansia berdasarkan umur banyak berusia antara 60-74 tahun 33(55\%), berpendidikan Tingkat SD 45(75\%), dan status perkawinan banyak lansia yang menikah 35(58.3\%).

Tabel. 2. Distribusi Responden Berdasarkan Kategori Umur, Pendidikan, Status Perkawinan Di Panti (N=46)

\begin{tabular}{ccc}
\hline Variabel & \multicolumn{2}{c}{$\begin{array}{c}\text { Jumlah } \\
\text { Persentasi (\%) }\end{array}$} \\
\hline Umur (Tahun) & Frekuensi & \\
1. $60-74$ & 35 & 76.1 \\
2. $75-90$ & 10 & 21.7 \\
3. $>90$ & 1 & 2.2 \\
Pendidikan & & \\
1. SD & 41 & 89.1 \\
2. SMP & 4 & 8.7 \\
3. SMA & 1 & 2.2 \\
Status & & \\
Perkawinan & 0 & 0 \\
1. Menikah & 46 & 100 \\
2. Janda & & \\
\hline
\end{tabular}

Berdasarkan karakteristik lansia menurut umur, pendidikan dan status perkawinan lansia yang tinggal di Panti pada tabel 4.2 diketahui mayoritas lansia berusia 60-74 tahun 35 (76.1\%), berpendidikan Tingkat SD 41(89.1\%) dan status perkawinan lansia 46 (100\%) lansia janda.

Hubungan strategi koping lansia yang tinggal di rumah dan di panti menggunakan uji chi-square dapat dilihat pada tabel berikut: 
Tabel. 3. Distribusi Strategi Koping Pada lansia yang tinggal di Rumah dan di panti $(\mathrm{N}=106)$

\begin{tabular}{|c|c|c|c|c|c|c|}
\hline \multirow[b]{2}{*}{ No } & \multirow[t]{2}{*}{ Strategi koping } & \multicolumn{2}{|c|}{ Lansia di Rumah } & \multicolumn{2}{|c|}{ Lansiadi Panti } & \multirow[b]{2}{*}{$\begin{array}{c}P \\
\text { Value }\end{array}$} \\
\hline & & Frekuensi & $\begin{array}{c}\text { Persentasi } \\
(\%)\end{array}$ & Frekuensi & $\begin{array}{c}\text { Persentasi } \\
(\%)\end{array}$ & \\
\hline 1 & Strategi Problem Focused Coping & 0 & 0 & 0 & 0 & \\
\hline & 2. Jarang digunakan & 1 & 1.7 & 8 & 17.4 & \\
\hline & 3. Sering digunakan & 28 & 46.7 & 28 & 60.9 & \\
\hline & 4. Selalu digunakan & 31 & 51.7 & 10 & 21,7 & 0.001 \\
\hline
\end{tabular}

2 Strategi Emotional Focused

Coping

1. Tidak digunakan

2. Jarang digunakan

3. Sering digunakan

4. Selalu digunakan

$\begin{array}{ccccc}0 & 0 & 0 & 0 & \\ 1 & 1.7 & 16 & 34.8 & \\ 44 & 73.3 & 23 & 50 & \\ 15 & 25 & 7 & 15.2 & 0.001\end{array}$

$3 \quad$ Strategi Religious Coping

$\begin{array}{lccccc}\text { 1. Tidak digunakan } & 0 & 0 & 0 & 0 & \\ \text { 2. Jarang digunakan } & 0 & 0 & 0 & 0 & \\ \text { 3. Sering digunakan } & 14 & 23.3 & 9 & 21.7 & \\ \text { 4. Selalu digunakan } & 46 & 76.7 & 37 & 78.3 & 0.412\end{array}$

Dari Tabel 3 data strategi koping diperoleh persentase tertinggi penggunaan strategi Problem focused coping pada lansia di rumah termasuk kategori selalu digunakan (51.7\%), dan pada lansia yang tinggal di panti persentase tertinggi pada kategori sering digunakan (60.9\%), hasil uji statistik menunjukkan ada perbedaan yang signifikan penggunaan strategi koping problem focused coping lansia yang tinggal di rumah dan panti $(P$ value $<0.05)$. Data presentasi tertinggi penggunaan strategi koping emotional focused coping pada lansia yang tinggal dirumah termasuk kategori sering digunakan (73.3\%), sedangkan lansia yang tinggal dipanti pada kategori sering digunakan (50\%), hasil uji statistik menunjukkan ada perbedaan yang signifikan penggunaan emotional focused coping lansia yang tinggal di rumah dan panti $(P$ value $<0.05)$. Data persentase tertinggi penggunaan strategi religious coping lansia tinggal dirumah pada kategori selalu digunakan $(76.7 \%)$ dan lansia yang tinggal di panti pada kategori selalu digunakan juga (78.3\%), hasil uji statistik menunjukkan tidak ada perbedaan strategi religious coping lansia yang tinggal di rumah dan panti $(P$ value $>0.05)$.

\section{Pembahasan}

Tujuan dari penelitian ini adalah untuk mengetahui hubungan tempat tinggal dengan strategi koping yang digunakan lansia. Hasil analisa data penelitian tentang gambaran karakteristik lansia yang tinggal dirumah diketahui proporsi lansia berdasarkan umur banyak berumur antara 60-74 tahun 33(55\%), sangat banyak berpendidikan pada kategori SD 45(75\%) dan banyak lansia status perkawinan menikah 35(58.3\%), sedangkan analisa data pada lansia yang tinggal di Panti diketahui proporsi lansia berdasarkan umur sangat 
banyak ditemukan umur antara 60-74 tahun 35(76.1\%), sangat banyak lansia berpendidikan pada kategori SD 41(89.1\%), dan status perkawinan lansia 46(100\%) janda.

Hasil analisa bivariat menunjukkan ada hubungan antara strategi problem focused, emotion focused coping dengan lansia yang tinggal di rumah dan dipanti dan strategi religous coping tidak ada perbedaan antara lansia yang tinggal dirumah dengan di panti. Penelitian ini menunjukkan bahwa lansia yang tinggal di rumah dan di panti telah menggunakan strategi koping yang cukup variatif dalam memecahkan masalah yang mereka hadapi, kolaborasi ketiga strategi problem focused coping, emotional focused, dan religous coping merupakan langkah paling tepat dan akan membawa pengaruh yang sangat baik pada individu yang sedang dihadapkan masalah.

Hasil penelitian ini sesuai dengan pendapat Lazarus dan Folkman (1984) yang mengatakan bahwa emotional focused coping lebih banyak digunakan pada situasi yang tidak mampu diubah karena keterbatasan sumber daya. Keadaan lansia dipanti dapat digambarkan dengan sumber stres yang banyak dan kondisi kesehatan lansia yang lemah akibat penyakit fisik sehingga sangat memungkinkan bagi lansia untuk berusaha menerima kenyataan. Mengingat lansia di keluarga banyak sistem pendukung yang menjadi sumber daya dalam mengatasi stres pada lansia. Sementara hasil penelitian juga menunjukkan bahwa lansia di Panti lebih banyak menggunakan strategi problem focused coping, hal ini cukup relevan mengingat lansia di Panti memiliki tingkat stres yang tinggi, sehingga memaksa mereka banyak menggunakan strategi problem focused coping disamping itu kondisi lansia di Panti yang hidup dalam satu lingkungan tempat tinggal dan sangat memungkinkan lansia berinteraksi dengan sesama termasuk menyelesaikan masalah dengan sesama lansia ketika terjadi konflik, karena menurut petugas Panti banyak sekali diantara lansia terjadi konflik antar sesamanya yang menjadi salah satu sumber stres pada lansia di Panti.

Penelitian ini menunjukkan bahwa lansia yang tinggal dirumah dan yang tinggal panti telah menggunakan strategi koping yang cukup variatif dalam memecahkan masalah yang mereka hadapi, dikarenakan tinggal permasalahan yang dihadapi berbeda antara lansia yang tinggal di rumah dengan di Panti, dan dimana lansia yang tinggal di Panti cenderung lebih banyak mengalami stress dibandingkan dengan lansia yang tinggal di rumah (Al-Nasir \& Alhadad, 1999). Didukung dengan hasil studi Intermill \& McCuan (1991), dalam Boyd \& Nihart, (1998) bahwa15-25\% lansia yang berusia 65 tahun keatas mengalami gangguan mental dan persentase tersebut meningkat dengan institusional, dan hasil penelitian lain oleh Mark (1997) yang mengatakan bahwa tempat tinggal sangat mempengaruhi emosional dan kesehatan fisik seseorang. Holmes dan Rahe (1967), dalam Miller, (2004) menempatkan lingkungan tempat tinggal sebagai sumber stress urutan ke27 dari 41 dengan skor 25 dari total skor 100.

Penelitian lain yang mendukung Watson (2003) berpendapat bahwa menurut pandangan sebagian lansia keberadaan dipanti adalah akibat penolakan keluarga terhadap dirinya sehingga membuat mereka semakin stress berada dipanti. Beberapa hasil studi ditemukan bahwa penempatan lansia di Panti bisa mendatangkan stress yang diakibatkan oleh timbulnya pertengkaran, ketakutan, kecemasan, dan menarik diri. Terlebih dalam konteks ke-Indonesiaan pada umumnya bahwa lansia seringkali menghayati penempatan mereka di Panti sebagai bentuk pengasingan dan perpisahan dari perasaan kehangatan yang terdapat dalam keluarga, apabila lansia yang masih memiliki anak dengan kondisi hidup berkecukupan. 
Hasil penelitian juga ditemukan bahwa lansia di keluarga memiliki status pernikahan, dibandingkan dengan di Panti semuanya berstastus janda. Fenomena ini mengambarkan kondisi status pernikahan lansia di Panti sudah tidak memiliki pasangan hidup dibandingkan dengan lansia yang tinggal di rumah. Berdasarkan teori kesinambungan (continuity theory), Miller (2004) mengemukakan proses penuaan erat kaitannya dengan adanya kesinambungan dalam siklus kehidupan lansia, dimana pengalaman hidup seseorang pada suatu waktu menjadi gambarannya pada saat ia menjadi lansia. Disini lansia cenderung untuk mempertahankan kelanjutan dari kebiasaan, dan kesenangan mereka secara konsisten sesuai kepribadian walau hidup tanpa pasangan (Stuard and Laraia, 2005), namun bagi individu yang tidak adaptif cenderung menimbulkan stress (Roy, 1997), dalam Tomey \& Alligood, (2006).

Upaya untuk mengurangi tekanan psikologis dapat pula dilakukan dengan cara mencari dukungan, keadaan ini terlihat dari upaya lansia yang sering berkonsultasi pada kepala panti dan penyedia kesehatan yang dianggap orang yang mampu memecahkan masalah mereka.

Menurut Pargament (1997) koping ditemukan ketika individu dihadapkan pada beberapa situasi, dimana koping merupakan proses yang multidimensional dan multilayered. Lebih jauh Pargament mengatakan ketika individu dihadapkan pada sebuah stressor maka akan berusaha mengatasinya dengan menggunakan beberapa respon dan tindakan yang mungkin untuk dilakukan. Lazarus (1984), dalam Hill, (2004) menegaskan bahwa koping adalah kekuatan yang stabil untuk mengatasi stress dan mengontrol emosi terhadap situasi stress. Lebih lanjut Lazarus menegaskan bahwa koping melibatkan kemampuan khusus yang dimiliki individu termasuk pemikiran dan pengalaman dalam memilih koping.

Hasil penelitian ini sesuai dengan hasil penelitian Al Nasir \& Al hadad (1999) yang menggambarkan bahwa persentase lansia yang tinggal di Panti cenderung mengalami stress dibanding yang tinggal di rumah. Penelitian lain Nurleli dan Istiadonna (2004) bahwa lansia yang tinggal dipanti mengalami depresi ringan sebanyak 37 orang $(54.41 \%)$, dimana stress memiliki hubungan yang sangat erat terhadap terjadinya depresi.

Seseorang apabila mengalami depresi atau masalah tidak mampu berespon dan beradaptasi terhadap stressor dengan baik, respon dan adaptasi terhadap stressor juga dipengaruhi oleh sistem dukungan yang dimiliki lansia. Rendahnya tingkat dukungan sosial menyebabkan lansia tidak dapat menggunakan strategi koping dengan baik. Didukung hasil penelitian Hariyanthi dan Istiadonna (2004) tentang tingkat dukungan sosial pada lansia di Panti Sosial Jroh Naguna Aceh, dari 68 orang responden $51.47 \%$ memiliki dukungan yang rendah. Hal ini menambah asumsi bahwa kondisi di panti rentan akan kejadian stress.

Strategi koping merupakan proses yang dinamik terhadap tingkat stress yang memiliki persamaan berbanding terbalik, dimana semakin tinggi penggunaan strategi koping makan akan menghasilkan adaptasi dan dapat meningkatkan integritas fisiologik dan psikologik individu sehingga akan semakin menurunkan tingkat stress. Strategi koping merupakan hal yang sangat berperan penting dalam upaya mengatasi stress. Namun keberhasilan perilaku koping didasarkan atas tiga fungsi yaitu: pertama, menghilangkan atau memodifikasi kondisi yang menimbulkan masalah; kedua, mengendalikan arti pengalaman yang dipersepsikan, dan ketiga mempertahankan konsekuensi emosional agar masih dalam batas kemampuan mengatasinya (Yani, 1997). 
Susi Andriani, Arti Lukitasari, Kartini Hasbalah

\section{PENUTUP}

\section{Kesimpulan}

Karakteristik dari 60 responden yang tinggal dirumah berusia antara 60-74 tahun $55 \%$, berpendidikan tingkat SD $75 \%$ dan status perkawinan menikah $58.3 \%$, sedangkan karakteristik dari 46 responden yang tinggal di Panti proporsi lansia berusia 60-74 tahun $76.1 \%$, berpendidikan tingkat SD $89.1 \%$ dan status perkawinan semuanya janda $100 \%$. Hasil penelitian ini membuktikan bahwa ada hubungan yang signifikan penggunaan strategi Problem Focused Coping dan Emotional Focused Coping lansia yang tinggal dirumah dengan di Panti Kota Banda Aceh ( $\mathrm{P}$ value $=0.001)$, sedangkan tidak ada penggunaan strategi religious coping dengan lansia yang tinggal dirumah dan di panti $(\mathrm{P}$ value > 0.05). Diharapkan Meningkatkan partisipasi keluarga dan lansia secara aktif dalam menggunakan stategi koping yang efektif untuk mengatasi stress pada lansia.

\section{DAFTAR PUSTAKA}

Akhmadi, 2009. Aging process. Retrieved Januari 26, 2014, from http://rajawana.com/artikel/kesehatan

Badan Pusat Statistik, 2009. Jurnal Census Bureau, Internasional Data base. U.S. ( http//:www.Internasional, diakses Tgl 27 April 2014).

Hariyanthi, Y \& Istiadonna. 2004. Tingkat Dukungan Sosial Pada Lanjut Usia di Panti Meuligo Jroh Naguna. Banda Aceh: PSIK Unsyiah. Tidak dipublikasikan.

Hernama. 2011. Hubungan Dukungan Keluarga Dengan Perilaku Lansia Dalam Pengendalian Hipertensi Di Kecamatan Koja Jakarta Utara. Fakultas Ilmu Keperawatan Universitas Indonesia.

Hill, S.A, 2004. Stres and Coping among Elderly African Americans. Dissertation Doctor of nursing Science, www.proquest.com/pqdauto, diakses tanggal 10 Maret 2014.

Keliat, B.A, 1999. Penatalaksanaan Stres. Jakarta: Penerbit Kedoktoran EGC.

Lazarus, R.S, \& Folkman, S, 1984. Stres, Appraisal, and Coping. Springer Publishing Company, Newyork.

Martono. 2006. Buku ajar geriatri: Ilmu kesehatan usia lanjut edisi ketiga. Jakarta: Fakultas Kedokteran UI.

Miller, C.A, 2004. Nursing for Wellness in Older Adult : Theory \& Praktice Philadephia : J.B. Lippinocort. Co.

Notoatmodjo, 2007. Metodelogi Penelitian Kesehatan. Jakarta: PT Rineka Cipta.

Yani, A. 1997. Analisa Konsep Koping; Suatu Pengantar; Jurnal Keperawatan Indonesia.

Prabowo, 2007. Treament Meta Music untuk Menurunkan Stres. http//www.google.co.id. di akses 18 Maret 2014.

Pukesmas Ulee Kareng Banda Aceh, 2014. Profil Lansia Tahun 2014.

Sunaryo, 2004. Psikologi untuk keperawatan. Jakarta: Penerbit Buku Kedokteran EGC.

Suyadi, 2007. Buku Ajar Geriatri. Jakarta: FIK UI

Tahlil T., Coveney, J., Woodman, R Ward, P,. (2013). Exploring Recommendation for an Effective smoking prevention program for Indonesian Adolescent. Asian Pacific Journal of Cancer Prevention. Vol 14. Diakses 5 Agustus di http://dx.doi.org/10.7314/APJCP.2013.14.2.865

Watson, R 2003. Perawatan pada Lanjut Usia. Jakarta: EGC

Wood, R.T. 1993. Psychosocial Management of Depression, International Review of Psychiatry, 5, 427-436 
Serambi Saintia

Volume VII, No.2, Oktober 2019

pISSN $2337-9952$

Jurnal Sains dan Aplikasi

eISSN $2656-8446$

Wenger, S, 2003. Religious Coping in People Ages Sixty Years and Older, www.proquest. Com/pqdauto. Diakses 9 Maret 2014. 